College. Mr. Cozens-IIardy has already made some interesting journeys in Montenegro and the neighbouring little-known parts of the west coast of the Balkan Peninsula which he intends to study further.

THE expedition of M. Delcommune by Lake Tanganyika appears to have been the most successful of all those sent out by the Katanga Company, as its leader has returned to Leopoldville, and will soon reach Europe to recount his experiences. The expeditions of Captain Stairs and Captain Bia, although successful in reaching their destination, were unfortunate in losing their leaders, and all the parties suffered terribly from sickness and famine. One of the interesting circumstances of these expeditions is the fact that a bronze tablet commemorating the death of Livingstone has been fixed to the tree at Old Chitambo's, where the great traveller died. This tablet was sent out in duplicate by Mr. $\Lambda$. L. Bruce of Edinburgh, son-inlaw of Dr. Livingstone, through Mr. Arnot, who being unable to reach Chitambo's himself, entrusted one of the tablets to Captain Bia, by whose party it was placed in position.

Mr. MaCKinNER's educational lectures, of which the eighth was delivered in the hall of the University of London on Friday night, continue to be well attended. The subject of the lecture was the Alps as a factor in European history, and the series of fine maps specially prepared for projection by the lantern enabled the development of the historical argument to be followed from point to point.

THE March number of the Scottish Geographical Magazine contains a valuable note by Prof. Mohn on the climate of Greenland, in which he epitomises his discussion of Dr. Nansen's results, published in a recent Ergänzungsheft of Petermann's Mitteilungen, and corrects it by the record of Peary's work. The isotherms (reduced to sea-level) run parallel to the coast, the interior being coldest at all seasons ; $30^{\circ} \mathrm{F}$. compared with $26^{\circ}$ on the coast for January, $30^{\circ}$ as compared with $50^{\circ}$ for July, and on the average for the year the centre of the land is probably about $-10^{\circ}$, while the coast has the temperature of $30^{\circ}$.

\section{THE CHATHAM ISLANDS AND AN ANTARCTIC CONTINENT.}

A $\mathrm{T}$ the last mecting of the Royal Geographical Society $\mathrm{Mr}$. H. O. Forbes discussed the question of the former extension of an Antarctic continent in relation to certain observations made during a recent visit to the Chatham Islands. The whole surface of these islands, especially Wharekauri and Rangiauria, is covered with a bed of peat in places over forty feet in depth - deeper in the northern part than in the southern-traversable in safety only by those acquainted with the country; for to the inexperienced eye there seems in most places no difference in the surface which can carry with safety both horse and rider, and that on which the lightest-footed pedestrian cannot venture without being engulfed. The surface of some of the larger and wetter depressions in the ground was covered with a brilliant-colourtd carpet of luxuriant mosses, emitting an aromatic fragrance, spread out in artless undesigned parterres of rich commingled green, yellow, and purple, and endless shades of these, warning the traveller of the existence of dangerous bogs beneath, and brightening miles of treeless moorland, which, but for those floating gardens, would be uninviting and uninteresting. In many places all over the island this great peat-moss is on fire, and has for years been smouldering underground, or burning in the exposed faces of the great pits which have now been burnt out. Dr. Dieffenbach mentions these fires at his visit in 1840 , and states that the combustion had begun before 1834 . 'They appear to have been burning in one part or another of the island ever since Dieffenbach's visit. A peculiarity in the main island that strikes the visitor very early is the occurrence of many lakes and tarns. These lakes arc, for the most part, on the eastern side, at the back of the low hills facing Petre Bay. The largest is fifteen miles long, over forty miles in circumference, and about ten and a half miles broad at its widest part.

Mr. Forbes's object in visiting the islands was to look for the remains of a fossil bird, fragments of which had been sent to him in New Zealand. These he discovered in considerable numbers, and found that the bird was no other than a species of Aphanapteryx, a large and remarkable member of the rail family, which lived contemporary with the celebrated dodo in

NO. I 220 , VOL 47 the Island of Mauritius, and was very similar to one of the extinct flightless birds of that island. Here was the only place in the world where it was known to exist, and where it had with the dodo preserved its fading race down to about two hundred years ago, when both of them passed away and perished for ever from among living things. In the Chatham lslands the remains of the Aphanapteryx were found in kitchen middens of the Morioris, showing that in this region of the world also it had survived down to comparatively recent date, just as the moa had in New Zealand.

In the Chatham Islands there still live several types of flightless birds scarcely represented elsewhere, except in widely separated oceanic islands. To account for their distribution it is necessary to reason backwards to former distributions of land and sea. The occurrence of similar forms in the three southern continents and in the islands which lie between them is most easily explained by a former Austral continent of considerable northern extension. The outlines of this continent it is of course impossible to trace with anything approaching to accuracy till we are in possession of a larger number of soundings. But it is not unlikely that the great meridional masses of land-or world ridges-which are probably of primeval antiquity extended to meet prolongations northward of the Antarctic continent, There is some evidence that the direct union of South Africa with the other continents was not for so prolonged a period as the others. The presence of the Aphanapteryx and other ocydromine birds both in the Mascarene and in the New Zealand continental Islands supports other evidence pointing to an extension of that area south by Marion and Kerguelen Islands, and of New Zea. land south, or of the $\Lambda$ ntarctic land north, by way of the Macquarrie, Auckland, and Antipodes Islands. It is interesting to observe that the great Pacific trough to the east of the Iongitude of New Zealand extends far south into the $\Lambda$ ntarctic region.

It is not necessary to suppose that all the southerly extending arms were connected contemporaneously with an Antarctic continent. It is impossible to account for the presence, for instance, of some South American forms in Australia and not in New Zealand; of Mascarene forms in the New Zealand region and not in Australia, or in Africa, or elsewhere, while we are unacquainted with the orography, the rivers and mountain barriers, of the submerged southern continent; and its various commissures may have been open at one time and closed at another. As there are, moreover, abundant evidences of great volcanic action over all the region, in New Zealand, South America, Mascarenia, and the Antarctic Islands, the permutations and combinations of the ups and downs of these lands, the openings and closings of the gates, paths, or stepping-stores, are beyond our computation.

The deductions as to an Antarctic continent, made on biological grounds, are supported by the depth of the circumpolar sea, so far as it is known. The submarine plateau of the Austral land slopes northward all round the shores of the known lands more gently than is the case along any other coast, and this would seem to indicate that, if elevaled, the land would form in great extent a continuation of the threc primal ridges of the globe southward, coalesced and spread out round the Pole, with, between these arms, the terminations of the great and permanent ocean troughs. How far these hypotheses-which are but a restatement, in great measure, of the investigations and conclusions of many distinguished naturalists, geologists, and geographers may be substantiated or refuted by future discoveries it is difficult to say; but the discovery of these interesting Aphanaptery'x bones on the Chatham Islands must always remain an important factor in the solution of this question.

There was an animated discussion.

\section{ARCHALLOGICAL WORK IN AMERICA.}

I $\mathrm{N}$ his report, just issued, on the Peabody Museum of American Archrology and Ethnology, Prof. Putnam is able to record the results of a very exceptional amount of useful work. This is due to the fact that while the officers of the Museum have discharged their usual duties many special archroological and ethnological researches have also been carried on with a view to the collection of material for the Chicago Exhibition, Prof. Putnam says :--

Never before his such an extensive field of anthropological research been covered in two years' time, and it is desirable to place on record what has been accomplished. In the north, 